\title{
Miliary Tuberculosis with Postpartum Involvement of the Central Nervous System
}

\author{
Postpartum Santral Sinir Sistemi Tutulumu ile Giden Miliyer Tüberküloz
}

(1) Mehmet Balal ${ }^{1}$, (1) Aslıhan Candevir Ulu², (1) Meltem Demirkıran ${ }^{1}$

${ }^{1}$ Cukurova University Faculty of Medicine, Department of Neurology, Adana, Turkey

${ }^{2}$ Cukurova University Faculty of Medicine, Department of Infectious Diseases and Clinical Microbiology, Adana, Turkey

Keywords: Miliary tuberculosis, central nervous system, postpartum

Anahtar Kelimeler: Miliyer tüberküloz, santral sinir sistemi, postpartum

Dear Editor,

A 32-year-old female patient presented with numbness of the right hand and right side of the face. She had no systemic illness and she had undergone infertility treatment during seven years of marriage. The patient became pregnant with in vitro fertilization, and she was admitted to hospital with high fever at the $24^{\text {th }}$ week of pregnancy and was diagnosed as having salpingitis, and intravenous antibiotherapy treatment was applied. She underwent a cesarean section due to vaginal bleeding at the $28^{\text {th }}$ week of pregnancy and had a healthy premature baby. Fifteen days after giving birth, her symptoms of numbness of the right hand and right side of the face began. The numbness episodes lasted about five minutes and repeated several times during the day. The patient, who had more frequent episodes after the second month, was hospitalized for further examination and treatment. Although the medical history of the patient was normal except for infertility, it was learned that a sibling of the patient had a diagnosis of tuberculosis.

The neurologic examination on admission was as follows: She was conscious, cooperative and oriented. Cranial nerve examination was intact, she had no motor deficits, superficial tactile sensation and cerebellar tests were intact, and deep tendon reflexes were normoactive. She had bilateral flexor plantar response, vibration and position senses were intact, and gait was normal.

In laboratory examinations, there were no significant pathologic findings except mild iron deficiency anemia on routine complete blood count and blood biochemistry. The erythrocyte sedimentation rate was $70 \mathrm{~mm} / \mathrm{h}$. She had normal chest X-ray and electrocardiography of the patient was in sinus rhythm.
Electroencephalography revealed slow and sharp wave asymmetry in the left frontotemporal area and the current symptoms were not compatible with epileptic seizures. Cerebral and cervical magnetic resonance imaging (MRI) revealed multiple parenchymal lesions in the cerebrum, cerebellum, and brainstem, with dimensions not exceeding $1 \mathrm{~cm}$ and peripheral thick ring-like enhancement,

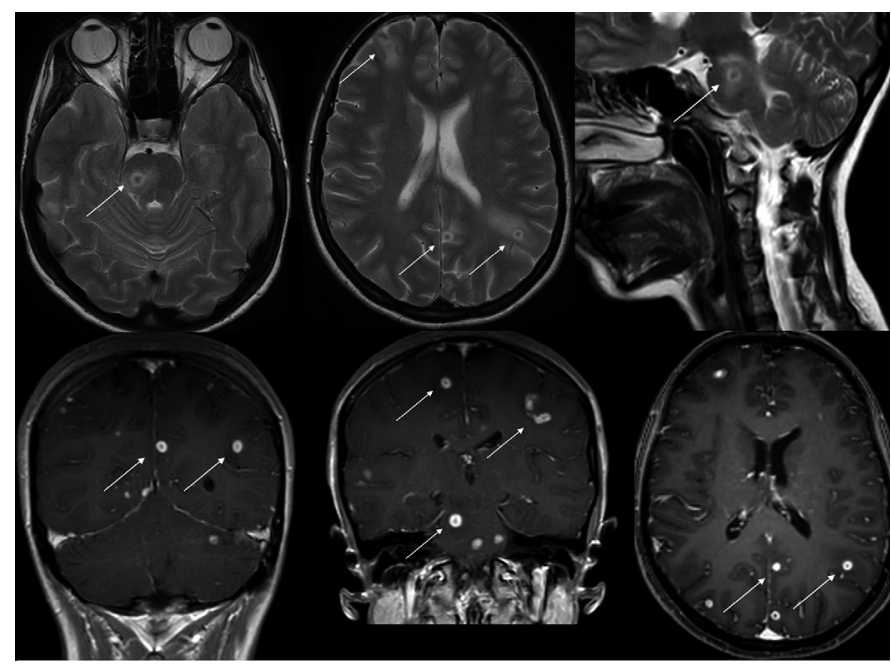

Figure 1. Cerebral magnetic resonance imaging showing multiple tuberculomas in the cerebrum, cerebellum and brainstem with dimensions not exceeding $1 \mathrm{~cm}$ and peripheral thick ring-like enhancement and some causing vasogenic edema.

Address for Correspondence/Yazışma Adresi: Mehmet Balal MD, Cukurova University Faculty of Medicine, Department of Neurology, Adana, Turkey Phone: +905055446949 E-mail: memet_balal@hotmail.com ORCID ID: orcid.org/0000-0001-8320-6597

Received/Geliş Tarihi: 24.01.2018 Accepted/Kabul Tarihi: 16.02.2018

${ }^{\circ}$ Copyright 2018 by Turkish Neurological Society

Turkish Journal of Neurology published by Galenos Publishing House 
and some causing vasogenic edema (Figure 1). Although the lesions were considered to be tuberculosis granulomas, magnetic resonance spectroscopy and diffusion-weighted MRI examination were recommended for the differential diagnosis. Metabolic values were not specific and there was no acute diffusion limitation. Cerebrospinal fluid (CSF) examination revealed a protein concentration of $43 \mathrm{mg} / \mathrm{dL}$, a lactate concentration of $1.37 \mathrm{mmol} / \mathrm{L}$, and glucose a concentration of $53 \mathrm{mg} / \mathrm{dL}$ (concurrent blood glucose level was $78 \mathrm{mg} / \mathrm{dL}$ ). No cells were detected on direct microscopic examination and cytologic examination was normal. All infectious parameters including tuberculosis examined from the CSF were normal. There was no growth in the CSF culture. Abdominopelvic ultrasonography revealed gallbladder sludge. Computed tomography examination of the thorax and abdomen revealed an appearance compatible with miliary tuberculosis of the lungs.

Following a positive QuantiFERON test result, the patients was accepted as having miliary tuberculosis and was transferred to the infectious diseases clinic (Figure 1). Although tuberculosis is a major health problem in developing countries, disseminated tuberculosis infections of the central nervous system (CNS) are very rare (1). Extrapulmonary involvement of tuberculosis accounts for $10-20 \%$ of all cases $(2,3)$. Fallopian tuberculosis is one of the regions where extrapulmonary involvement is seen and it can disseminate from there by hematogenous spread (4). Tuberculosis cases with CNS involvement can present with very different clinical conditions. These include meningitis, encephalitis, arachnoiditis and findings of space-occupying lesion depending on granulomas (3). Tuberculomas, the most common form of CNS tuberculosis in the parenchyma, are small, tumor-like structures. They may cause focal neurologic signs and seizures due to increased intracranial pressure (3). Our patient was considered as having miliary tuberculosis with CNS involvement from salpingitis due to immunosuppression caused by pregnancy.

Ethics

Informed Consent: Consent form was filled out by all participants.

Peer-review: Internally peer-reviewed.

Authorship Contributions

Surgical and Medical Practices: M.B., M.D., Concept: M.B., M.D., Design: M.B., A.C.U., Data Collection or Processing: M.B., M.D., Analysis or Interpretation: M.B., A.C.U., Literature Search: M.B., A.C.U., M.D., Writing: M.B.

Conflict of Interest: No conflict of interest was declared by the authors.

Financial Disclosure: The authors declared that this study received no financial support.

\section{References}

1. Ray S, Talukdar A, Kundu S, Khanra D, Sonthalia N, et al. Diagnosis and management of miliary tuberculosis: current state and future perspectives. Ther Clin Risk Manag 2013;9:9-26.

2. Kim CH, Lim JK, Yoo SS, et al. Diagnostic performance of the QuantiFERONTB gold in-tube assay and factors associated with nonpositive results in patients with miliary tuberculosis. Clin Infect Dis 2014;58:986-989.

3. Sharma SK, Mohan A, Sharma A, Mitra DK. Miliary tuberculosis: new insights into an old disease. Lancet Infect Dis 2005;5:415-430.

4. Poyrazoglu OK, Timurkaan M, Yalniz M, Ataseven H, Dogukan M, Bahcecioglu IH. Clinical review of 23 patients with tuberculous peritonitis: presenting features and diagnosis. J Dig Dis 2008;9:170-174. 